\title{
Coloration Characteristic and Population Genetic Analysis of Wild-Captured Giant Tiger Shrimp (Penaeus monodon) from Aceh Timur
}

\author{
Indriatmoko ${ }^{1 *}$, Dimas A Hedianto ${ }^{1}$, Sari Budi Moria² and Didik WH Tjahjo ${ }^{1}$ \\ ${ }^{1}$ Research Institute for Fish Enhancement \\ Jl. Cilalawi No 1, Jatiluhur, Purwakarta, Jawa Barat, 41152 Indonesia. \\ IInstitute for Mariculture Research and Development \\ Singaraja, Penyabangan, Gerokgak, Buleleng, Bali, 81001 Indonesia \\ Email: indriatmoko.bp2ksi@outlook.com
}

\begin{abstract}
Giant tiger shrimp (Penaeus monodon) has become a prime commodity in Indonesia which was produced by aquaculture and capture fisheries activities. Aceh Province, in this case mostly represented by Aceh Timur District, was well-known as the center of wild-captured-adult giant tiger shrimp. Several previous investigations had proved for its high-quality shrimp spawner in producing good eggs in quality and quantity under artificial spawning condition. Two main interesting points of wild giant tiger shrimp from Aceh Timur came from their coloration and population clusters. This report was aimed to provide that information pre-preliminary and highlighted quantitative information of coloration characteristic through RGB (Red Green Blue) and CIE Lab color space data analysis, as well as, 16S rDNA-PCR-RFLP genetic comparison among four population clusters in Aceh Timur Waters. The color analysis resulted in significant differences between wild-captured and pond-cultured giant tiger shrimp which produced $R$ value $0.1524 \pm 0.0091$ and $0.1268 \pm 0.0004$, respectively. Total pixel analysis through $L^{*} a * b *$ color space has distinguished detailed differentiation between wild-captured and pond-cultured giant tiger shrimp acquired images. It is known that most of the wild-captured image pixels were concentrated in quadrant I $(+a,+b)$ while pond-cultured in quadrant II $(-a,+b)$ and III $(-a,-b)$. Genotyping of represented samples from 4 population clusters, i.e. Aceh Tamiang, Langsa, Peudawa, and Julok produce 2 haplotype composite, AAA and $A A B$. Among 4 clusters, it was found that Julok has become the only cluster which has a different haplotype composite ratio (1:1) (D 0.0348, V 0,9501) from the others (4:1)(V 0.9504).
\end{abstract}

Key words: Aceh Timur; CIE Lab; PCR-RFLP; Penaeus monodon; RGB.

\section{Introduction}

In aquaculture, Aceh Timur Waters is wellknown as a source of high quality of wild-adult giant tiger shrimp (Penaeus monodon) for their potential broodstock (Lante et al., 2015). P. monodon exploitation in Aceh Timur was held intensively and recorded as prime commodities in this area (Hedianto et al., 2016). Information related to $P$. monodon in Aceh Province had reported previously which is mainly discussing about stock and diversity information (Wardana, 2011; Nawang et al., 2014; Hedianto et al., 2016). Eventhough, comprehensive information related to $P$. monodon characteristic in this area remains limited.

Our investigation conducted in 2015 found interesting findings regarding giant tiger shrimp in Aceh Timur waters. Population distribution of the shrimps was found to be clustered on 4 identified locations (unpublished data). Traditionally, fishermen at several landing centers (Aceh Tamiang, Langsa, Peudawa, and Julok) were capturing tiger shrimps at those areas. Another interesting characteristic of giant tiger shrimps from Aceh Timur was their reddish coloration. This is an attracting visualization compared to other wild-captured tiger shrimps from different locations in Indonesia.

The coloration of shrimps was positively correlated with product quality. This visual appearance indicated high nutrition contents (Boonyaratpalin et al., 2001). Some assessment for coloration quantification was improved in numerous reported investigation, either using standardized and sophisticated instruments colorimetry and spectroscopy (Parisenti et al., 2011) or image acquisitions (Wade et al., 2014). In Indonesia, information regarding the coloration measurement was here qualitatively. This representation the predominant color based on observer subjectivity visually (Amin et al., 2012; Wade et al., 2014).

Genetic information of black tiger shrimp in Indonesia had been reported previously (Sugama et al., 2002; Walther et al., 2011; Purnamaningrum et 
al., 2016). Nevertheless, genetic characterization information for a small region, specifically in Aceh Timur, is limited. Eventhough, this information was essential to provide local genetic characteristic to provide genetic biodiversity resource information (Sherry et al., 2001). This investigation reported genetic characteristic of four population cluster considered based on acoustic surveys result through RFLP analysis of 16S rDNA target gene (Lavery et al., 2004). This method gave us more advantages in providing genetic information based on DNA fragmentation post to enzyme digestion. In addition, this method had been proved to provide tiger shrimp genetic characteristic on the previous report (Bouchon et al., 1994; Klinbunga et al., 2001; Prastowo et al., 2009).

\section{Materials and Methods}

\section{Image acquisition and processing}

Fresh giant tiger shrimp from captured (wildtype) and cultured (pond-type) were used for image analysis ( $n_{\text {wild }}=10, n_{\text {pond }}=10, C L=4-7.2 \mathrm{~cm}$ ). Image samples were acquired using $12 \mathrm{MP}$ resolution camera under daylight illuminance and clear white background. In order to minimize light bias, image acquisition was conducted in short time duration $(n=$ 10). Furthermore, preprocessing image data were employed by involving pixel normalization (1). Prior to normalization process, controlled image reduction was applied in order to suit data dimension for the software maximum data range. The original images, which were having $2200 \times 1400$ pixel dimension (containing more than 3 million pixels), reduced to $400 \times 400$ pixels (containing more than 160.000 pixels) and enhanced from $72 \mathrm{dpi}$ to $96 \mathrm{dpi}$ resolution. This was essential to conduct in order to maintain data quality during reduction processes. Thus, image normalization was conducted using equation (Vezhnevets et al., 2003). Normalization step produce white color subtraction and turn the background of original in to black color $(R=G=B=$ $0)$. This process revealed stronger object color and by this, the $L$ value (corresponding to light/ brightness/illuminance related factors) become neglected in further analysis processes. Classification of dominance color on each pixel was divided into three segmented images using Kmeans equation (Likas et al., 2003).

Segmentation results were then re-calculated to gather average R, G, and B value from images sample, respectively. Calculation of color area from each segmented image were conducting by RGB to binary image conversion (colored pixel= 1 , black pixel=0) using available syntax in Matlab [im2bw]. Identification of pixel color distribution an analysis using CIE Lab color space was employed. As previously described, the $L$ * value was no longer use since it has been neglected during image normalization. The $a^{*}$ and $b^{*}$ values were used to inform detailed color position of images pixel. A normalized RGB image was converted to Lab image using [srgb2lab] syntax. To provide higher resolution of the segmented image, 6 segmentation were classified using nearest neighbor equation (Duin et al., 2000). One Way Anova analysis facilitated by Origin 7 (OriginLab, US) was used to determine the difference between coloration characteristic of wildtype and cultured-type shrimp.

\section{DNA extraction, amplification, and digestion}

Freshly landed $P$. monodon $\left(\mathrm{n}_{\text {total }}=40, \mathrm{CL}=\right.$ $3.2-7.3 \mathrm{~cm}$ ) purchased from fishermen located in Aceh Tamiang, Langsa, Peudawa, and Julok. These fishermen operate their trammel net in different locations closing to population cluster desired in this investigation. Fresh tissue was collected and preserved in $96 \%$ ethanol, then transported to the laboratory and put the samples in the fridge.DNA extraction conducted using chelex $10 \%$ in TE buffer ( $\mathrm{pH} \mathrm{8,0)} \mathrm{with} 25 \mathrm{mg}$ tissue sample, approximately. Extracted genomic DNA was purified using QIAcolumn purification kit based on manufacturer protocol. This is essential to prevent the presence of inhibitors.

Gene segment was amplified using PCR (Polymerase Chain Reaction). Amplification used based on Klinbunga et al. (2001), 16SrDNA F : 5'CGC CTG TTT AAC AAA AAC AT -3' and 16 SrDNA R : 5'- CCG GTC TGA ACT CAG ATC ATG T -3'. Amplification was conducted under pre-denaturation $95^{\circ} \mathrm{C}$ for 2 minutes, followed by 29 cycles consisting of denaturation $93^{\circ} \mathrm{C}$ for 30 seconds; annealing $50^{\circ} \mathrm{C}$ for the $30 \mathrm{~s}$; and extension $72^{\circ} \mathrm{C}$ for $45 \mathrm{~s}$ and a final extension of $72^{\circ} \mathrm{C}$ for 5 minutes. The amplicons were tested electrophoresis using 1,5\% agarose gel in 1X TBE (Tris-borate-EDTA) buffer. The amplicons proceeded to digested using Alu I, HaellI, EcoRI, Hinfl, Mbol, and Ddel. Restriction product was visualized using $2 \%$ agarose gel electrophoresis in $2 X$ loading dye. The results were scored and analyzed using TFPGA (Miller, 1997).

\section{Results and Discussion}

\section{Coloration characteristic}

In this investigation, image processing using K-means and nearest neighbor algorithm have successfully segmented the objects. RGB-based segmented image produces 3 image segment which was visualized strong red, light red, and black object 
cluster for wild-type $P$. monodon image and strong green, light red, and black for cultured-type $P$. monodon image (Figure 1.). Color quantification facilitated by RGB color space analysis classified 3 main colors which were forming single pixel coloration by the ratio of $\mathrm{R}$ (red), $\mathrm{G}$ (green), and $\mathrm{B}$ (blue) value. Theoretically, absolute red color were consisted by $R=1, G=0, B=0$, so for others. Extracted $R G B$ value from normalized image have shown the varied value of $R, G$, and $B$. For the wildtype the R, G, and B value are 0.1524, 0.1024 and 0.0922 , respectively. For the cultured type, the R, G and $B$ value are $0.1268,0.1131$, and 0.0973 respectively. These values represent quantitatively green coloration in cultured-type tiger shrimps (Figure 2.). The Strong red coloration of wild-type tiger shrimps achieved the highest value $(0.1524 \pm$ 0.0091). Color variation between wild-type and cultured-type of giant tiger shrimp were significantly different. One Way ANOVA analysis show $P$ value for comparison of $\mathrm{R}, \mathrm{G}, \mathrm{B}$ from both sample type were 0,00023 (R), 0,000057 (G), 0,0068 (B) $(P<0.05)$.

The segmented images produced by K-means classification were calculated to measure the pixel area of each segment. Generally, Kmeans classifications were not identified green coloration on wild-captured shrimps. Strong red and light red becoming dominant color among all wild-type samples and covered $53.55 \pm 8.43 \%$ for strong red coloration and $30.97 \pm 8.87 \%$ for light red coloration (all red coloration $84.52 \%$, approximately) (Table 1.). Pond-cultured shrimps were dominantly covered $64.32 \pm 4.50 \%$ by green coloration, small-light reddish smear coloration was found in $17.80 \pm 0.67$ $\%$ coverage pixel area. Dark black coloration was found in both samples type which was mainly located in the abdominal segment. This coloration covered either wild-type or pond-type in equal proportion $(15.46 \pm 4.98 \%$ and $17.87 \pm 5.14 \%$, respectively).

According to this finding, wild-captured tiger shrimps from Aceh Timur covered by red coloration from the carapace, pereopods, and pleopods to the most of the abdominal segments (Figure 1.). Among all observed samples, wild-type shrimps have similar coloration characteristic. Nevertheless, pondcultured shrimps have light red coloration on their pleopods and pereopods. RGB color space, in general, considered as an effective parameter to observe color range from an object, but, more comprehensive observation for the non-absolute RGB color (Mendoza et al., 2006). CIE Lab color space has been used for numerous applications regarding to aquatic organism and its derivation products color analysis (Misimi et al., 2007; Sreenath et al., 2008; Maury-Ramirez et al., 2013).
These wide range applications were triggered by its ability to provide single-pixel color distribution visualized in Cartesian coordinate systems (Leon et al., 2006). Since human visual color opinion becomes unreliable, CIE Lab had been used as color space analysis for color standardization (Connolly and Fleiss, 1997).

CIE Lab color analysis proved detailed singlepixel coloration between both samples type. Wildtype shrimps pixel color concentrated in quadrant I which represent orange-red coloration characteristic $(+a,+b)$ (Figure 3.). Highest Pixel densities were observed in range (a10, b5) to (a40, b35). In contrast, pixel coloration of pond-type shrimps distributed on wider area range that covering quadrant I, II, and III (anti-clockwise quadrant order). Nevertheless, reduced pixel (see Figure 3. on black marked area) showed pixel densities were concentrated in greenish $(-a,-b)$, and yellowish-green $(-a,+b)$ area.

Crustacean coloration was mainly affected by the presence of astaxanthin content in hypodermal and exoskeleton (Lopez et al., 2002). In a natural condition, astaxanthin was found as a pigmentprotein complex, crustacyanin (Krawczyk and Britton, 2001). This complex form affects to wavelength shifting which turns original red coloration of astaxanthin to greenish-blue color effect (Parisenti et al., 2011; Wade et al., 2014). Denaturation of the pigment-protein complex would release free-formed astaxanthin and reveal the original red color of astaxanthin (Pacheco et al., 2009; Jantakoson et al., 2012).

Wild-captured tiger shrimps from Aceh Timur Waters naturally has belonging red coloration. The coloration possibly caused by several factors, i.e. depth pressure and feeding behavior (Parisenti et al., 2011; Jantakoson et al., 2012). Our previous investigation found that most of the wild-type shrimps, which was captured using trammel net in $50 \mathrm{~m}$ depth, were used small crustacean as their main diet (Anonymous, 2016). It was related to the several investigations that proved that astaxanthin synthesis was greatly affected by the carotenoid-rich diet (Boonyaratpalin et al., 2001; Amin et al., 2012). Besides that, an ecological assessment of toxic materials was essential to conduct. Martinez et al. (2014) reported that $\mathrm{Cu}$ contamination significantly related to the strong red coloration in shrimps.

\section{Genetic population characteristic}

Amplification conducted by targeting 16SrDNA gene resulted amplicon 560 bp in size, approximately. Then, this PCR product was digested 

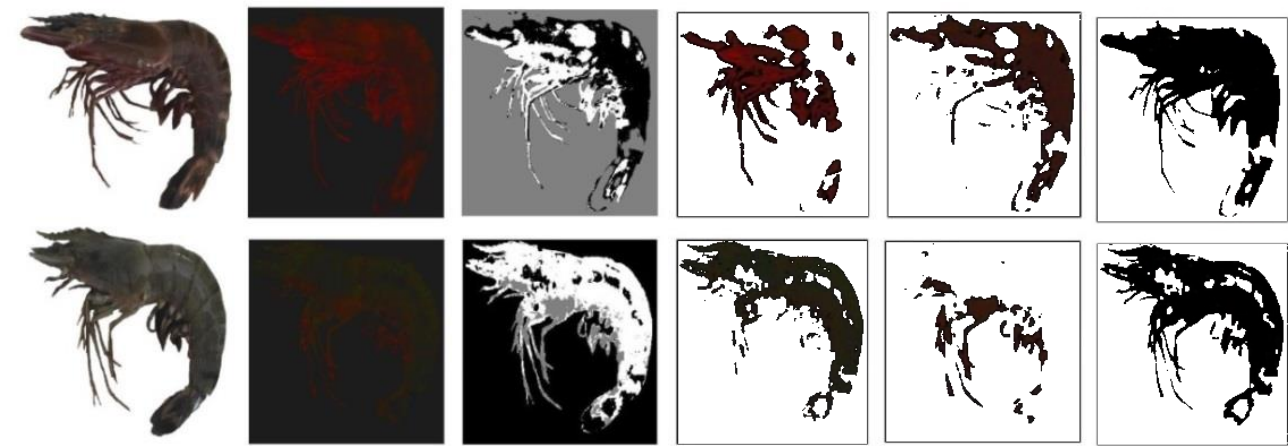

Figure 1. Giant tiger shrimp image processing step, from left to right: original image (upper image: wild shrimp, bottom image: pond shrimp), normalized image, total segmented image, segmented image 1, segmented image 2, and segmented image 3.

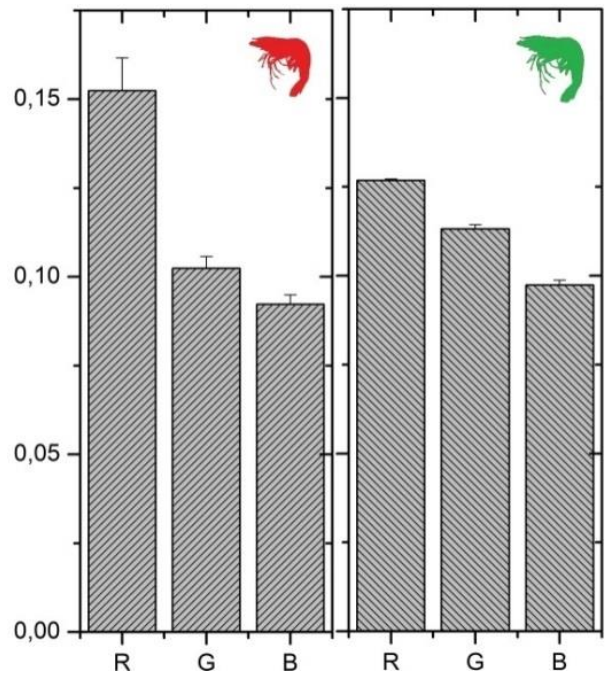

Figure 2. RGB average value from the image of Giant tiger shrimp from wild (red) and cultured pond (green).

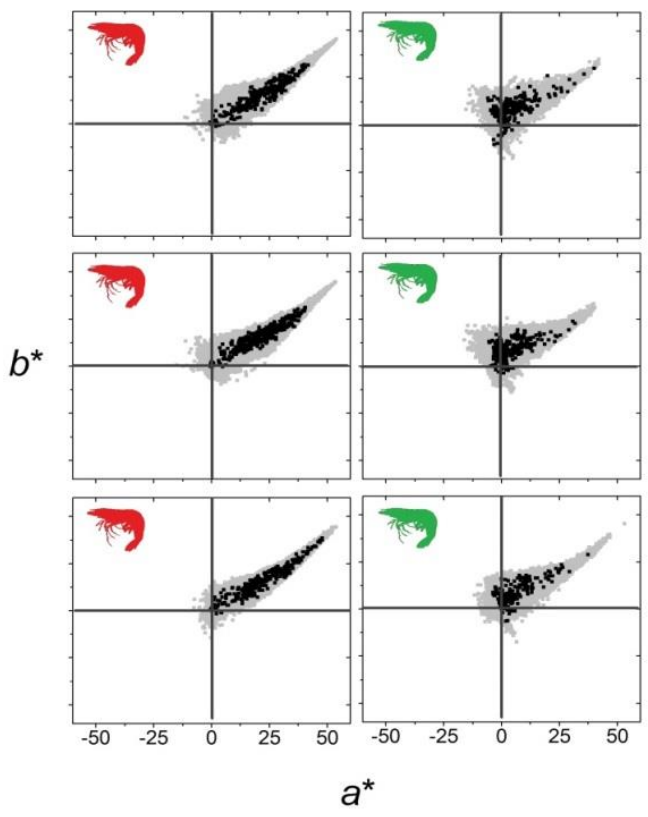

Figure 3. $a^{*}$ and $b^{*}$ color space coordinate position of representative image samples of Giant tiger shrimp from wild (red) and pond (green). Pixel coordinate area is marked in gray represented total pixel color $(n=160.000)$ while black marked area represented reduced pixel area $(n=1000)$. 
using 6 restriction enzymes, i.e., Alu I, HaellI, EcoRI, Hinfl, Mbol, and Ddel. Consistent restrictions were found in Haelll, Hinfl, and Mbol.Haelll cutting position was 5'..GG $\downarrow$ CC..3', Hinfl cutting position was 5'..G $\downarrow$ ANTC..3', and Mbol cutting position was 5'..\GATC..3'. According to digestion product produced by those 3 enzymes, two alleles were identified as AAA and AAB (Table 2.). This result indicated low haplotype variance presence among population clusters.

Composite haplotype AAA was known as dominated haplotype in the observed giant tiger shrimp from all investigated locations. 80\% haplotype composite in Aceh Tamiang, Langsa, and Peudawa, as well as $50 \%$ in Julok, were dominated by AAA. These findings show that AAA haplotype shrimps are distributed in all observed samples. Giant tiger shrimp heterozygosity in Aceh Timur Water was considered as low heterozygosity especially in Aceh Tamiang, Langsa, and Peudawa (0.1067). Giant tiger shrimp heterozygosity from Julok was slightly greater than those others three locations (0.1667). Thus, genetic variances show insignificant variation among the population (0.9501-0.9504) (Table 3.). Low heterozygosity indicated close genetic distance among the observed population (Table 4.). Based on 16SrDNA gene, digested by Haelll, Hinfl, and Mbol, Tiger shrimp from Aceh Tamiang, Langsa, and Peudawa show similar genetic character (100\%). In Julok, $3,48 \%$ differences in genetic character was found (Figure 4.)
An acoustic survey conducted in 2015 gave interesting result regarding to the position of giant tiger shrimp population cluster in Aceh Timur waters (Anonymous, 2016). It was identified that in coastaloffshore of Aceh Timur waters, the tiger shrimps biomass clustered in Aceh Tamiang, Langsa, Peudawa, and Julok (Anonymous, 2016). This report was considered as the Sampling location in the current investigation. In population genetic study, the represented locations were essential to provide representative population genetic data (Petit et al., 1998). One of the advantages of using genetic population analysis, the ability to provide the current condition of inter and/or intrapopulation variation. This information gave us new perception to describe environmental pressure which may be caused by nature or anthropogenic factors (Wilson and Clarke, 1996). Giant tiger shrimp capture rate in Aceh Timur water was considered as overexploited (Hedianto et al., 2016). This condition was possibly triggered to decrease the genetic variation of giant tiger shrimp. Several previous investigations reported significant factors influencing low genetic variance, e.g. geographical barrier, inbreeding, and overfishing (Christiansen and Reyer, 2011; Pinsky and Palumbi, 2014; Willoughby et al., 2015)

16SrDNA gene was shown low variation among all samples (Figure 4). Short genetic distance among population clusters may considerably to conclude as single stock population. These results are possible to use in conservation strategy policy. Larger population comparison studies were

Table 1. Pixel area detection using the image of Giant tiger shrimp from wild and pond.

\begin{tabular}{cccc}
\hline Sample & Strong red area pixel & Red area pixel & Black area pixel \\
\hline Wild & $53.55 \pm 8.43 \%$ & $30.97 \pm 8.87 \%$ & $15.46 \pm 4.98 \%$ \\
Sample & Red area pixel & Green area pixel & Black area pixel \\
Pond & $17.80 \pm 0.67 \%$ & $64.32 \pm 4.50 \%$ & $17.87 \pm 5.14 \%$ \\
\hline
\end{tabular}

Table 2. Haplotype distribution of Giant tiger shrimp from each sampled location

\begin{tabular}{ccccc}
\hline Haplotype & \multicolumn{4}{c}{ Haplotype Frequencies (\%) } \\
\cline { 2 - 5 } Composite & Aceh Tamiang & Langsa & Peudawa & Julok \\
\hline AAA & 1.6 & 1.6 & 1.6 & 1 \\
AAB & 0.4 & 2 & 2 & 1 \\
n-Allele & 2 & 2 & 2 & 2 \\
\hline
\end{tabular}

Table 3. Heterozygosity analysis and genetic variation result of Giant tiger shrimp from sampled location

\begin{tabular}{cccc}
\hline Population & Observed Heterozygosity & Expected Heterozygosity & Genetic variance \\
\hline Aceh Tamiang & 0.1067 & 0.1123 & 0.9501 \\
Langsa & 0.1067 & 0.1123 & 0.9501 \\
Peudawa & 0.1067 & 0.1123 & 0.9501 \\
Julok & 0.1667 & 0,1754 & 0.9504 \\
\hline
\end{tabular}


Table 4. Genetic distance result among Giant tiger shrimp population

\begin{tabular}{|c|c|c|c|c|}
\hline Population & Aceh Tamiang & Julok & Peudawa & Langsa \\
\hline Aceh Tamian & & & & \\
\hline Julok & 0.0348 & & & \\
\hline Peudawa & 0.0000 & 0.0348 & & \\
\hline Langsa & 0.0000 & 0.0348 & 0.0000 & \\
\hline
\end{tabular}
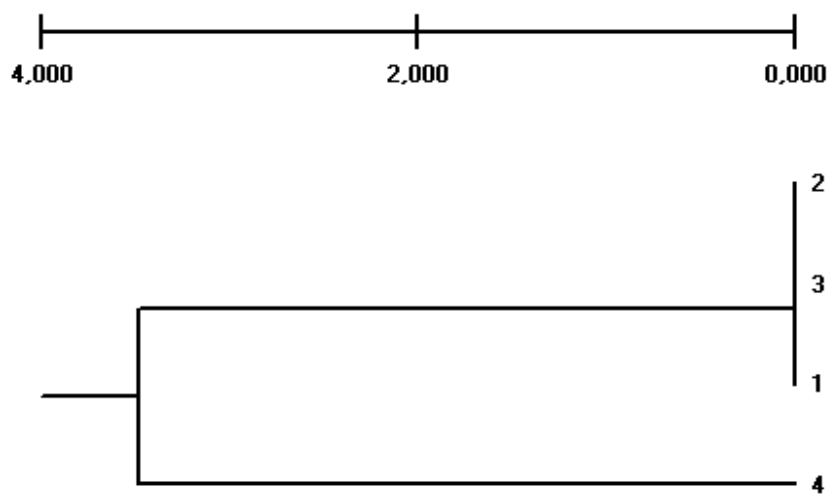

Figure 4. Genetic distance dendrogram of Giant tiger shrimp based on UPGMA cluster.

conducted previously by Sugama et al. (2002). P. monodon tissue sample was studied from Aceh, Cilacap, Madura, Tarakan, Bali, Dompu, and Sulawesi Selatan. Six polymorphic locus show genetic distance in range $0.2-4.7 \%$. Based on this investigation, it is clear that there is a low $P$. monodon genetic variation observed. In contrast, a significant variation (24\%) of $P$. monodon collected from Malaysia and Australia using 16S rDNA marker was known. Thus, Indo-pacific $P$. monodon was estimated to have a high variety of genetic characteristic by geographic position.

\section{Conclusion}

Coloration characteristic of giant tiger shrimp from Aceh Timur quantified by RGB and CIE Lab color space had shown significant differences between wild and pond type. RGB and Lab color space analysis showed that strong red and light red coloration were found consistently among all wildtype samples pixel. Genotyping through 16SrDNA PCR-RFLP analysis remains showing a capability to characterize the genetic population of giant tiger shrimp in smaller water area. Compared to larger geographic distance study, in this study, we found that small-barrier less aquatic ecosystem was still had $3.48 \%$ genetic differences potency.

\section{Acknowledgements}

The authors acknowledge Prof. Dr. Haryanti, MS for the suggestion and guidance throughout the study. This project was funded by Indonesian Ministry for Marine and Fisheries Affairs through "Giant Tiger Shrimp ( $P$. monodon) conservation status in Aceh Timur" research project.

\section{References}

Amin, M.I., Lili, W. \& Priyadi, A. 2012.Peningkatan Kecerahan Warna Udang Red Cherry (Neocaridina heteropoda) Jantan melalui Pemberian Astaxanthin dan Canthaxanthin dalam Pakan. J. Per. Kel., 3:243-252.

Anonymous. 2016. Laporan teknis kegiatan penelitian kawasan konservasi induk udang windu (Penaeus monodon) di pantai timur Aceh, kabupaten Aceh Timur. BP2KSIBALITBANG KP.

Boonyaratpalin, M., Thongrod, S., Supamattaya, K., Britton, G. \& Schlipalius, L. 2001. Effects of Beta-carotene source, Dunaliella salina, and astaxanthin on pigmentation, growth, survival, and health of Penaeus monodon. Aqua. Res. 32(s1): 182-190. doi: 10.1046/j.1355-557x. 2001.00039x

Bouchon, D., Souty-Grosset, C. \& Raimond, R. 1994. Mitochondrial DNA variation and markers of species identity in two penaeid shrimp species: Penaeus monodon Fabricius and $P$. japonicus Bate. Aqua. 127(2-3): 131-144. doi: 10.1016/ 0044-8486(94)90420-0

Christiansen, D.G. \& Reyer, H.U. 2011. Effects of geographic distance, sea barriers and habitat 
on the genetic structure and diversity of allhybrid water frog populations. Heredity, 106(1): 25-36. doi: 10.1038/hdy.2010.37

Connolly, C. \& Fleiss, T. 1997. A study of efficiency and accuracy in the transformation from RGB to CIELAB color space. IEEE Transactions on Image Processing, 6(7): 1046-1048. doi: 10.1109/83.597279

Duin, R., Juszczak, P., Paclik, P., Pekalska, E., De Ridder, D., Tax, D. \& Verzakov, S. 2000. A matlab toolbox for pattern recognition. PRTools version, 3: 109-111.

Hedianto, D.A., Suryandari, A. \& Tjahjo, D.W.H. 2016. Dinamika populasi dan status pemanfaatan udang windu Penaeus monodon (Fabricus, 1789) di perairan Aceh Timur. J. Penelitian Perikanan Indonesia, 22(2): 71-82. doi: 10.15 578/jppi.22.2.2016.71-82

Jantakoson, T., Kijroongrojana, K. \& Benjakul, S. 2012. Effect of high pressure and heat treatments on black tiger shrimp (Penaeus monodon Fabricius) muscle protein. Int. Aqua. Res. 4(1): 19. doi: 10.1186/2008-6970-4-19

Klinbunga, S., Siludjai, D., Wudthijinda, W., Tassanakajon, A., Jarayabhand, P. \& Menasveta, P. 2001. Genetic heterogeneity of the giant tiger shrimp (Penaeus monodon) in Thailand revealed by RAPD and mitochondrial DNA RFLP analyses. Mar. Biotechnol. 3(5): 428438. doi: 10.1007 /s10126-001-0055-9

Krawczyk, S.A. \& Britton, G. 2001. A study of proteincarotenoid interactions in the astaxanthinprotein crustacyanin by absorption and Stark spectroscopy; evidence for the presence of three spectrally distinct species. Biochimica et Biophysica Acta (BBA) Protein Structure and Molecular Enzymology. 1544(1-2): 301-310. doi: 10.1016/S0167-4838(00) 00242-9

Lante, S., Laining, A. \& Parenrengi, A. 2015. Performa reproduksi induk udang windu (Penaeus monodon Fab.) jantan alam dan domestikasi tambak. Prosiding Forum Inovasi Teknologi Akuakultur, 693-700.

Lavery, S., Chan, T., Tam, Y. \& Chu, K. 2004. Phylogenetic relationships and evolutionary history of the shrimp genus Penaeus derived from mitochondrial DNA. Molecul. Phylogeny. Evol. 31(1): 39-49. doi: 10.1016/j.ympev.200 3.07.015

Leon, K., Mery, D., Pedreschi, F. \& Leon, J. 2006. Color measurement in Lab- units from RGB digital images. Food Res. Int. 39(10): 10841091. doi: 10.1016/j.foodres.2006.03.006

Likas, A., Vlassis, N. \& Verbeek, J. J. 2003. The global k-means clustering algorithm. Pattern Recognition 36(2): 451-461. doi: 10.1016 /S0031-3203(02)00060-2

Lopez, A.R., Guerrero, I. \& Huerta, S. 2002. Astaxanthin extraction from shrimp waste by lactic fermentation and enzymatic hydrolysis of the carotenoprotein complex. J. Food Sci. 67(3): 1002-1006. doi: 10.1111/j.1365-2621.2002. tb09443.x

Martinez, A., Romero, Y., Castillo, T., Mascaro, M., Lopez-Rull, I., Simoes, N., Arcega-Cabrera, F., Gaxiola, G. \& Barbosa, A. 2014. The effect of copper on the color of shrimps: redder is not always healthier. PloS One. 9(9): 1-5. doi: 10.1371/journal.pone.0107673

Maury-Ramirez, A., De Muynck, W., Stevens, R., Demeestere, K. \& De Belie, N. 2013. Titanium dioxide based strategies to prevent algal fouling on cementitious materials. Cement and Concrete Composites, 36(): 93-100. doi: 10.1016/ j.cemconcomp.2012.08.030

Mendoza, F., Dejmek, P. \& Aguilera, J.M. 2006. Calibrated color measurements of agricultural foods using image analysis. Postharvest Biol. Technol. 41(3): 285-295. doi: 10.1016/ j.postharvbio.2006.04.004

Miller, M. P. 1997. Tools for population genetic analyses (TFPGA) 1.3: A Windows program for the analysis of allozyme and molecular population genetic data. Computer software distributed by author, 4: 157.

Misimi, E., Mathiassen, J.R. \& Erikson, U. 2007. Computer vision based sorting of Atlantic salmon (Salmo salar) fillets according to their color level. J. Food Sci. 72(1): 30-35. doi: 10.1 111/j.1750-3841.2006.00241.x

Nawang, A., Trismawanti, I., \& Parenrengi, A. 2014. Produktifitas telur dan daya tetas induk udang windu (Penaeus monodon) asal Aceh dan Takalar. Prosiding Forum Inovasi dan Teknologi Akuakultur. pp: 701-707.

Pacheco, N., Garnica-Gonzaez, M.N., RamarezHernandez, J. Y., Flores-Albino, B., Gimeno, M., Barzana, E. \& Shirai, K. 2009. Effect of temperature on chitin and astaxanthin recoveries from shrimp waste using lactic acid bacteria. Biores. Technol. 100(11): 2849-2854. doi: 10.1016/ j.biortech.2009.01.019 
Parisenti, J., Beireo, L., Maraschin, M., Mourino, J., Do Nascimento Vieira, F., Bedin, L. \& Rodrigues, E. 2011. Pigmentation and carotenoid content of shrimp fed with Haematococcus pluvialis and soy lecithin. Aquacul. Nut. 17(2): 530-535. doi: 10.1111/ j.1365-2095.2010.00794.x

Petit, R.M.J., El Mousadik, A. \& Pons, O. 1998. Identifying populations for conservation on the basis of genetic markers. Conservation biology, 12(4): 844-855. doi: 10.1111/j.1523-1739.19 98.96489.x

Pinsky M.L. \& Palumbi, S.R. 2014. Meta-analysis reveals lower genetic diversity in overfished populations. Mol. Ecol. 23(1): 29-39. doi: 10.1111/mec.12509

Prastowo, B.W., Rahardianti, R., Nur, E.M. \&Taslihan, A. 2009. Profil Heterogenitas Genetik Induk Udang Windu (Penaeus monodon) Turunan F1 Melalui Analisis DNA Mitokondria-RFLP dan RAPD. J. Fish. Sci. 11(1): 25-30.

Purnamaningrum, A., Handayani, N.S.N., Trijoko, Handayani, C.R., Nuringtyas, T.R., Roto, R., Widyaparaga, A., Mahardika, M., Kusumaadmaja, A. \& Hadi, N. 2016. Assessment of genetic variation in outbreed and inbreed giant tiger shrimp (Penaeus monodon Fabricius, 1798) using ISSR marker. AIP Conference Proceedings, 1755(1): p140009. doi: 10.1063/1.4958570

Sherry, S. T., Ward, M.-H., Kholodov, M., Baker, J., Phan, L., Smigielski, E. M. \& Sirotkin, K. 2001. dbSNP: the NCBI database of genetic variation. Nucleic Acids Res. 29(1): 308-311. doi: 10.10 93/nar/29.1.308

Sreenath, P.G., Abhilash, S., Ravishankar, C.N. \& Gopal, T.S. 2008. Standardization of process parameters for ready to eat shrimp curry in tin free steel cans. J. Food Proc. Preservat. 32:
247 -269. doi: 10.1111/j.1745-4549.2008.00 177.x

Sugama, K., Benzie, J. \& Ballment, E. 2002. Genetic variation and population structure of the giant tiger prawn, Penaeus monodon, in Indonesia. Aquacul. 205(1-2): 37-48. doi: 10.1016/S0 044-8486(01)00662-7

Vezhnevets, V., Sazonov, V. \& Andreeva, A. 2003. A survey on pixel-based skin color detection techniques. Proc. Graphicon, 3: 85-92.

Wade, N.M., Paulo, C., Goodall, J., Fischer, M., Poole, S. \& Glencross, B.D. 2014. Quantitative methods to measure pigmentation variation in farmed Giant Tiger Prawns, Penaeus monodon, and the effects of different harvest methods on cooked colour. Aquacul. 433: 513-519. doi: 10.1016/j.aquaculture.2014.07.014

Walther, E., Schofl, G., Mrotzek, G., Sugama, K. \& Saluz, H.P. 2011. Paralogous mitochondrial control region in the giant tiger shrimp, Penaeus monodon (F.) affects population genetics inference: A cautionary tale. Mol. Phylogen. Evol. 58(2): 404-408. doi: 10.10 16/j.ympev.2010. 11.028

Wardana, M.Y. 2011. Kajian prospek komoditas induk udang windu pada kawasan pesisir perairan pantai di daerah Kabupaten Aceh Besar. J. Agrisep 12(1): 31-39. doi: 10.24815 /agrisep.v12i1.208

Willoughby, J.R., Fernandez, N.B., Lamb, M.C., Ivy, J. A., Lacy, R.C. \& DeWoody, J.A. 2015. The impacts of inbreeding, drift and selection on genetic diversity in captive breeding populations. Mol. Ecol., 24(1): 98-110. doi: 10.1111/mec.13020

Wilson, D. \& Clarke, A. 1996. The Shy and the Bold. Natural history. 9: 26-28. 